\title{
Planting and seasonal and circadian evaluation of a thymol-type oil from Lippia thymoides Mart. \& Schauer
}

\author{
Sebastião G. Silva1*, Pablo Luis B. Figueiredo ${ }^{1}$, Lidiane D. Nascimento ${ }^{2,3}$, Wanessa A. da Costa², \\ José Guilherme S. Maia ${ }^{1}$ and Eloisa Helena A. Andrade ${ }^{1,3}$
}

\begin{abstract}
Background: The oil and extracts of Lippia thymoides have been used for various medicinal and food applications. Entrepreneurs in the Amazon have been considering the economic exploitation of this plant. The present study evaluated the influence of the seasonal and circadian rhythm on the yield and composition of the essential oil of leaves and thin branches of a Lippia thymoides specimen cultivated in Abaetetuba, State of Pará, Brazil. The constituents of the oils were identified by GC and GC-MS and with the application of multivariate analysis: Principal Component Analysis (PCA) and Hierarchical Cluster Analysis (HCA).

Results: The predominance of oxygenated monoterpenes (70.6-91.8\%) was observed in oils, followed by monoterpene hydrocarbons (1.2 to 21.6\%) and sesquiterpene hydrocarbons (3.9 to 9.1\%). Thymol, thymol acetate, $\gamma$-terpinene, $p$-cymene, and (E)-caryophyllene were the first compounds. The mean thymol content was higher in the rainy season (seasonal: 77.0\%; circadian: 74.25\%) than in the dry period (seasonal: 69.9\%; circadian: 64.5\%), and it was influenced by climatic variables: rainfall precipitation, solar radiation, temperature, and relative humidity. For the circadian study, PCA and HCA analysis were applied to the constituents of oils from rainy and dry periods. Two groups were formed. A higher thymol content characterized the group 1, followed by (Z)-hexen-3-ol, a-thujene, a-pinene, a-phellandrene and humulene epoxide II, in minor percent. A higher content of p-cymene formed the group $2, y$-terpinene, thymol acetate and (E)-caryophyllene, followed by myrcene, a-terpinene, 1,8-cineole, terpinen-4-ol, methylthymol, and germacrene $\mathrm{D}$, in a low percentage.
\end{abstract}

Conclusions: The different chemical profiles found in the oils of L. thymoides must be associated with the environmental conditions existing at its collection site. The knowledge of this variation in the oil composition is essential from the ecological and taxonomic point of view, regarding the management and economic use of the species.

Keywords: Lippia thymoides, Verbenaceae, Essential oil composition, Seasonal and circadian study, Thymol

\section{Background}

Lippia L. is one of the largest genera of Verbenaceae, with nearly 100 species of herbs, shrubs and small trees distributed in the Neotropics and Africa [1]. Lippia thymoides Mart. \& Schauer (Verbenaceae) [syn. Lippia micromera var. tonsilis Moldenke, L. satureiaefolia Mart. \& Schauer, $L$. thymoides var. macronulata Moldenke, $L$.

\footnotetext{
*Correspondence: sebastiaogs@ufpa.br

1 Programa de Pós-Graduação em Química, Universidade Federal do Pará, Belém, PA 66075-900, Brazil

Full list of author information is available at the end of the article
}

thymoides var. tonsilis (Moldenke) Moldenke [2], is an aromatic plant with a shrub size $(1.0-2.0 \mathrm{~m}$ in height), endemic to the Northeast and Center-West of Brazil, with the distribution center in the states of Bahia and Minas Gerais, popularly known as "alecrim-do-mato", "alecrimdo-campo" and "alecrim-de-cheiro-miúdo" [3, 4]. The plant was introduced in the Brazilian Amazon, where it is known as "manjerona", particularly in the Municipality of Abaetetuba, State of Pará, Brazil. It is used in folk medicine, in baths for treatment of wounds, as antipyretic, digestive, in the treatment of bronchitis and rheumatism, 
for a headache and weakness, and as incense in the rituals of Umbanda and Candomblé $[3,5,6]$.

The essential oil can undergo a qualitative and quantitative change in several stages of the vegetative life of the plant because its metabolic activity has a chemical interconnection with the medium in which it is inserted. Some environmental factors contribute to this, among them, the circadian regime, which refers to the time of collection of the plant throughout the day, and the seasonality, which represents the time of collection during the year. Thus, the production of the oils can suffer variation due to environmental changes such as temperature, relative humidity, precipitation, solar radiation, among others, occurring during the day or a certain seasonal period $[7,8]$.

There are few reports on the composition of the essential oil of L. thymoides. Two specimens from Olindina and Feira de Santana, Bahia State, Brazil, presented leaf oils with $(E)$-caryophyllene as the main component, followed by other sesquiterpene hydrocarbons in a lower percentage $[9,10]$. The oil of another specimen, sampled in Belém, state of Pará, Brazil, presented thymol as the significant component [11]. Regarding the biological activity, the oils of $L$. thymoides with a predominance of $(E)$-caryophyllene, showed spasmolytic and antidiarrheal effects [12], besides antimicrobial activity and significant relaxing potential in pre-contracted smooth muscle [10]. Crude extracts of $L$. thymoides (leaves, flowers, and fine branches) also showed antimicrobial activity, healing, and anti-thermic action in rodents [13, 14].

The present study evaluated the circadian and seasonal variation of the essential oil of a thymol rich specimen of Lippia thymoides, previously submitted to a cultivation test in the city of Abaetetuba, State of Pará, Brazil, intending to its future economic exploitation.

\section{Experimental}

\section{Planting of Lippia thymoides}

The vegetative propagation of Lippia thymoides was initiated with the donation of a seedling, by a resident of the Municipality of Abaetetuba, State of Pará, Brazil. From this seedling, other two seedlings were prepared which, together with the initial seedling, formed the three matrices. Then, the plant was propagated with stem cuttings (30 stakes, 25 to $30 \mathrm{~cm}$ long) in disposable plastic cups, using black earth as a substrate, according to [15]. The experiment was maintained under these conditions for 5 weeks, with watering of the plants at the end of the day. Then, the 30 seedlings were transplanted to the field, arranged in two lines with a spacing of $50 \mathrm{~cm}$ between each seedling, without soil fertilization. Following the same methodology, after 3 months another 30 seedlings were produced. The planting occurred in the locality known as "Colônia Velha" $\left(01^{\circ} 46^{\prime} 15.9^{\prime \prime} \mathrm{S} / 48^{\circ} 47^{\prime} 02.2^{\prime \prime}\right.$ W), PA 151 Road, Municipality of Abaetetuba, State of Pará, Brazil.

\section{Plant material}

For the seasonal study, the leaves and thin branches (aerial parts) of $L$. thymoides were collected monthly, between January and December, always on the 15th day, at 6 a.m. For the circadian study, the collections were carried out in February (rainy period) and September (dry period), at the hours of 6 a.m., 9 a.m., 12 a.m., 3 p.m., 6 p.m. and 9 p.m. Samples were collected in triplicate. The botanical identification was made by comparison with an authentic specimen of Lippia thymoides and samples of the plant (MG 213373) were incorporated into the Herbarium "João Murça Pires" of the Museu Paraense Emílio Goeldi, in the city of Belém, State of Pará, Brazil.

\section{Climate data}

Climatic factors such as relative air humidity, temperature, and rainfall precipitation were obtained monthly from the website of the Instituto Nacional de Meteorologia (INMET, http://www.inmet.gov.br/portal/), of the Brazilian Government. The meteorological data were recorded by the automatic station A-201 of the city of Belém, with a range of $100 \mathrm{~km}$. The plant cultivation area and sample collection are located in the municipality of Abaetetuba, about $52 \mathrm{~km}$ from the city of Belém, thus within the radius of action of the A-201 automatic station, which is equipped with a Vaisala system of meteorology, model MAWS 301 (Finland).

\section{Plant processing}

The fresh plant material (leaves and fine branches) was cut, homogenized and submitted to hydrodistillation $(65 \mathrm{~g}, 3 \mathrm{~h})$ in a Clevenger type glass apparatus. After extraction, the oil was dried over anhydrous sodium sulfate. The determination of the residual water content of the plant material was carried out in a moisture-determining balance using infrared. The oil yield was calculated in $\% \mathrm{~m} / \mathrm{v}(\mathrm{mL} / 100 \mathrm{~g})$ [16].

\section{Analysis of oil composition}

Qualitative analysis was carried out on a THERMO DSQ II GC-MS instrument, under the following conditions: DB-5 ms ( $30 \mathrm{~m} \times 0.25 \mathrm{~mm} ; 0.25 \mu \mathrm{m}$ film thickness) fused-silica capillary column; programmed temperature: $60-240{ }^{\circ} \mathrm{C}\left(3{ }^{\circ} \mathrm{C} / \mathrm{min}\right)$; injector temperature: $250{ }^{\circ} \mathrm{C}$; carrier gas: helium, adjusted to a linear velocity of $32 \mathrm{~cm} / \mathrm{s}$ (measured at $\left.100{ }^{\circ} \mathrm{C}\right)$; injection type: splitless $(2 \mu \mathrm{L}$ of a 1:1000 hexane solution); split flow was adjusted to yield a 20:1 ratio; septum sweep was a constant $10 \mathrm{~mL} / \mathrm{min}$; 
EIMS: electron energy, $70 \mathrm{eV}$; temperature of ion source and connection parts: $200{ }^{\circ} \mathrm{C}$. Quantitative data regarding the volatile constituents were obtained by peak-area normalization using a FOCUS GC/FID operated under GC-MS similar conditions, except for the carrier gas, which was nitrogen. The retention index was calculated for all the volatiles constituents using an n-alkane (C8C40, Sigma-Aldrich) homologous series. Individual components were identified by comparison of both mass spectrum and GC retention data with authentic compounds which were previously analyzed with the aid of commercial libraries containing retention indices and mass spectra of volatile compounds commonly found in essential oils $[17,18]$.

\section{Statistical analysis}

Statistical significance was assessed by the Tukey test $(\mathrm{p}<0.05)$ and the Pearson correlation coefficients $(\mathrm{R})$ were calculated to determine the relationship between the parameters analyzed (GraphPad Prism, version 5.0). The Principal Component Analysis (PCA) was applied to verify the interrelation in the composition of the oils of the leaves, collected at different times and months (software Minitab free 390 version, Minitab Inc., State College, PA, USA). The Hierarchical Grouping Analysis (HCA), considering the Euclidean distance and complete linkage, was used to verify the similarity of the samples of the oils, based on the distribution of the constituents selected in the PCA analysis.

\section{Results and discussion}

The rational planting of $L$. thymoides can determine a better use for this species in the Amazon, with basis on the economic exploitation of the essential oil of some known chemical types. The crop, established in underutilized areas of secondary forests and savannas, can lead to it densification and consequent commercial exploitation.

\section{Planting of $L$. thymoides}

A cultivation test was carried out in a dystrophic yellow latosol, medium texture, with solar radiation incident only in the morning, presenting excellent development. Plant material collection began 6 months after planting the first seedlings. At the sixth month, the plants varied from 68 to $103 \mathrm{~cm}$ in height. At 8 months of age, the plant registered a maximum height of $180 \mathrm{~cm}$. At each collection, 3 to 4 plants were cut at the height of $25 \mathrm{~cm}$ from the soil, and their leaves and thin branches (aerial part) were destined to the experiment predicted in this work. The regeneration of these plants took from 3 to 4 months.

\section{Essential oil yield vs climate parameters}

The climatic parameters, temperature, solar radiation, precipitation and relative humidity were monitored in the 12 months, to evaluate the seasonality in the yield and composition of $L$. tymoides essential oil. The mean values of temperature and solar radiation, between January and December, varied from 22.9 to $26.5{ }^{\circ} \mathrm{C}$ and 873.2 to $1123 \mathrm{~kJ} / \mathrm{m}^{2}$, respectively. Likewise, mean relative humidity and mean rainfall ranged from 55.45 to $70.32 \%$ and 50 to $540 \mathrm{~mm}$, respectively. Based on the precipitation data, the rainy season was from January to June, with a mean of between 250 and $540 \mathrm{~mm}$, and the dry period was from July to December, varying between 50 and $180 \mathrm{~mm}$. On the other hand, the temperature remained almost constant with an annual average of $23.86^{\circ} \mathrm{C} \pm 0.87$ (Fig. 1).

In the Brazilian Amazon, only two seasons are considered throughout the year: a dry period and a rainy period and, among them, a few months of transition [19]. Due to the hot and humid climate of the region, precipitation is a parameter with high heterogeneity and significant variability of local and time. Thus, the dry period (called the Amazonian summer) and the rainy season (called the Amazonian winter) may present changes in its beginning and end.

The yield of the oils of $L$. thymoides in the seasonal study was $0.3 \%$ (May and June) to $1.3 \%$ (January, November, and December), with a mean of $0.7 \pm 0.38 \%$ in the rainy season months, and $0.9 \pm 0.36$ in the months of the dry period (see Table 2). Thus, throughout the year, the yields of oils did not present a statistically significant difference between the two periods ( $p>0.05)$. However, in the seasonal study, oil yield showed a strong correlation with the relative humidity (Table 1 ). In the circadian study, the oil yields were $0.7 \%(6 \mathrm{pm})$ to $1.1 \%(12 \mathrm{am})$ in the rainy season and from $0.5 \%(3 \mathrm{pm})$ to $0.9 \%(9 \mathrm{am})$ in the dry period. No statistical difference $(\mathrm{p}>0.05)$ was observed in mean yields of the circadian study, which was $0.88 \pm 0.13 \%$ in the rainy season and $0.72 \pm 0.15 \%$ in the dry period. In the circadian survey, analyzing the yields of the oils about the collection times, a strong correlation directly proportional to the temperature $\left(\mathrm{r}^{2}\right.$ 0.71 ) and a strong correlation inversely proportional to the humidity $\left(\mathrm{r}^{2}-0.75\right)$ were observed, as can be seen in Table 1. Previously, studies with $L$. thymoides reported an oil yield of $0.71 \%$ for a sample collected in the city of Belém, State of Pará, Brazil (11) and an oil yield between 2.14 and $2.93 \%$ for another sample harvested in the city of Feira de Santana, State of Bahia, Brazil [10]. These differences in the yields of L. thymoides oils can be attributed to the diversity of the climatic factors in the plant collection areas. 


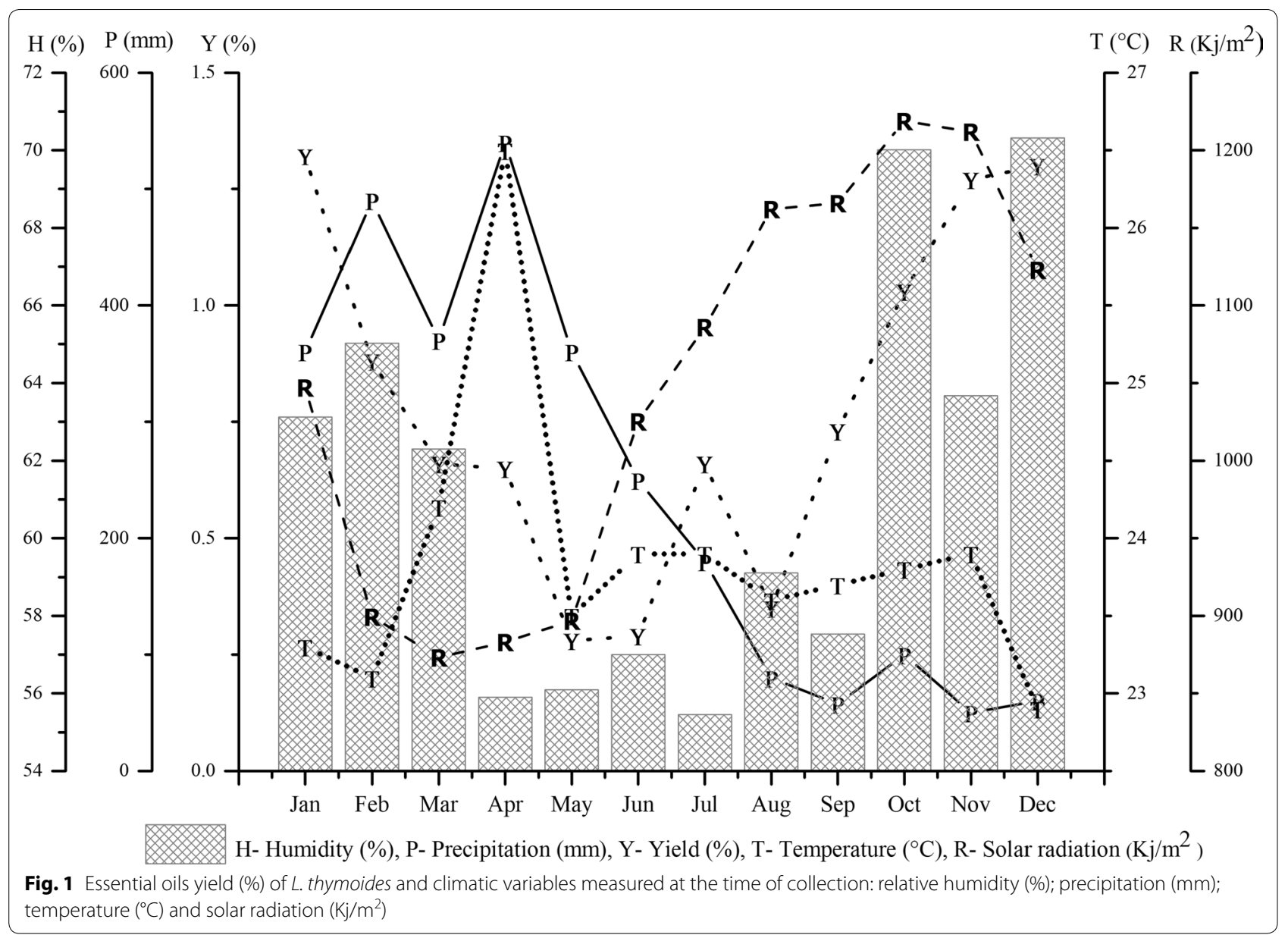

Table 1 Correlation between climatic factors and seasonal and circadian studies, based on the yields of $L$. thymoides oils and thymol content (\%)

\begin{tabular}{llcc}
\hline Climatic factors & Seasonal study & Circadian study & Thymol \\
\hline & Correlation coefficient $\left(\mathrm{r}^{2}\right)$ & \\
Temperature $\left({ }^{\circ} \mathrm{C}\right)$ & -0.26 & 0.71 & 0.45 \\
Precipitation $(\mathrm{mm})$ & -0.22 & & $0.77^{*}$ \\
$\begin{array}{c}\text { Solar radiation }(\mathrm{Kj} / \\
\left.\mathrm{m}^{2}\right)\end{array}$ & 0.39 & & $-0.81^{*}$ \\
Relative humidity (\%) & $0.74^{*}$ & -0.75 & -0.12 \\
\hline
\end{tabular}

* Significant at $p \leq 0.05$

\section{Composition of oils}

The identification of the constituents of the oils by GC and $\mathrm{GC}-\mathrm{MS}$ was on average $99.3 \%$ and $99.6 \%$ in the seasonal $(S)$ and circadian $(C)$ studies, respectively. In total, forty-five constituents were identified, and they are listed in Tables 2 and 3.

The predominance of oxygenated monoterpenes (S: 76.3-91.8\%; C: 70.6-83.2\%) was observed in the oils, followed by monoterpene hydrocarbons (S: 1.2-13.7\%; C: 12.4-21.6\%) and sesquiterpene hydrocarbons (S: 3.9-8.4\%; C: 3.6-9.1\%). Thymol (S: 65.7-80.0\%; C: 61.5-77.8\%), thymol acetate (S: $4.8-13.7 \%$; $C: 4.5-$ 9.0\%), $\gamma$-terpinene (S: 0.5-6.4\%; C: 4.8-8.4\%), $p$-cymene (S: $0.5-6.4 \%$; C: $4.1-8.8 \%)$, and $(E)$-caryophyllene (S: $2.9-6.2 \%$; C: $2.9-6.3 \%)$ were the principal compounds. The mean thymol content was higher in the rainy season (S: $77.0 \%$; C: $74.3 \%$ ) than in the dry period (S: 69.9\%; C: 64.5\%). The climatic variables that most influenced the thymol content were rainfall precipitation (directly proportional) and solar radiation (inversely proportional), as can be seen by the correlation data in Table 1.

A similar study with Lippia origanoides Kunth, collected in Santarém, State of Pará, Brazil, whose primary component was carvacrol, a thymol isomer, did not show a statistical difference for the two collection periods (rainy and dry seasons), regarding the carvacrol content [20]. Besides that, in previous works was observed that oils of Lippia species occurring in the Intercontinental Amazon have shown significant amounts of thymol, 
Table 2 Seasonal study of the Lippia thymoides oils during 12 months

\begin{tabular}{|c|c|c|c|c|c|c|c|c|c|c|c|c|c|c|}
\hline \multirow[t]{3}{*}{ Oil constituents (\%) } & \multicolumn{14}{|c|}{ Oil yields (\%) } \\
\hline & \multirow[t]{2}{*}{$\mathrm{RI}_{\mathrm{C}}$} & \multirow[t]{2}{*}{$\mathbf{R I}_{\mathbf{L}}$} & \multirow{2}{*}{$\begin{array}{l}1.3 \\
\text { Jan }\end{array}$} & \multirow{2}{*}{$\begin{array}{l}0.9 \\
\text { Feb }\end{array}$} & \multirow{2}{*}{$\begin{array}{l}0.7 \\
\text { Mar }\end{array}$} & \multirow{2}{*}{$\begin{array}{l}0.7 \\
\text { Apr }\end{array}$} & \multirow{2}{*}{$\begin{array}{l}0.3 \\
\text { May }\end{array}$} & \multirow{2}{*}{$\begin{array}{l}0.3 \\
\text { Jun }\end{array}$} & \multirow{2}{*}{$\begin{array}{l}0.7 \\
\text { Jul }\end{array}$} & \multirow{2}{*}{$\begin{array}{l}0.4 \\
\text { Aug }\end{array}$} & \multirow{2}{*}{$\begin{array}{l}0.7 \\
\text { Sep }\end{array}$} & \multirow{2}{*}{$\begin{array}{l}1.0 \\
\text { Oct }\end{array}$} & \multirow{2}{*}{$\begin{array}{l}1.3 \\
\text { Nov }\end{array}$} & \multirow{2}{*}{$\begin{array}{l}1.3 \\
\text { Dec }\end{array}$} \\
\hline & & & & & & & & & & & & & & \\
\hline (3Z)-Hexenol & 853 & 850 & & 0.1 & 0.1 & & & 0.1 & 0.1 & 0.1 & 0.1 & 0.1 & 0.1 & 0.1 \\
\hline a-Thujene & 922 & 924 & 0.2 & 0.6 & & & & & 0.1 & 0.2 & 0.1 & 0.2 & 0.3 & 0.2 \\
\hline Sabinene & 971 & 969 & & 0.1 & & & & & & & & 0.1 & 0.1 & 0.1 \\
\hline 1-Octen-3-ol & 979 & 974 & & & & & & 0.1 & 0.1 & 0.1 & 0.1 & 0.1 & 0.1 & 0.1 \\
\hline Myrcene & 987 & 988 & 0.5 & 1.0 & 0.2 & 0.3 & & 0.1 & 0.3 & 0.8 & 0.6 & 0.6 & 0.8 & 0.7 \\
\hline a-Phellandrene & 1000 & 1002 & & 0.1 & & & & & 0.1 & 0.1 & & 0.1 & 0.1 & 0.1 \\
\hline a-Terpinene & 1015 & 1014 & 0.3 & & 0.2 & 0.2 & 0.1 & 0.1 & 0.3 & 1.0 & 0.9 & 0.6 & 0.6 & 0.7 \\
\hline p-Cymene & 1022 & 1020 & 3.8 & 6.4 & 2.2 & 2.5 & 0.5 & 0.6 & 2.9 & 5.3 & 4.8 & 3.3 & 4.8 & 5.4 \\
\hline Limonene & 1025 & 1024 & & & & 0.1 & 0.1 & 0.1 & & 0.2 & 0.2 & 0.1 & 0.1 & 0.1 \\
\hline 1,8-Cineole & 1028 & 1026 & & & & 0.4 & & 0.5 & 0.6 & 0.7 & 0.5 & 0.4 & 0.2 & 0.2 \\
\hline$(E)$ - $\beta$-Ocimene & 1047 & 1044 & & & & & & & 0.1 & 0.1 & 0.1 & 0.1 & 0.1 & 0.1 \\
\hline$\gamma$-Terpinene & 1058 & 1054 & 3.8 & 4.9 & 1.8 & 2.0 & 0.5 & 0.5 & 3.2 & 5.9 & 6.4 & 4.1 & 4.5 & 5.0 \\
\hline cis-Sabinene hydrate & 1064 & 1065 & & 0.1 & & & & & 0.1 & & 0.1 & 0.2 & 0.1 & 0.2 \\
\hline Terpinolene & 1087 & 1086 & & & & & & 0.1 & 0.1 & 0.1 & 0.1 & 0.1 & 0.1 & 0.1 \\
\hline Linalool & 1094 & 1095 & & 0.1 & 0.1 & & & 0.1 & 0.1 & 0.1 & 0.1 & 0.1 & 0.1 & 0.1 \\
\hline Camphor & 1143 & 1141 & & & & & & 0.1 & 0.1 & 0.1 & 0.1 & 0.1 & 0.1 & 0.1 \\
\hline Borneol & 1167 & 1165 & & & & 0.1 & & 0.1 & 0.1 & 0.1 & 0.1 & & 0.1 & 0.1 \\
\hline Umbellulone & 1169 & 1167 & 0.3 & 0.2 & 0.1 & & 0.1 & 0.2 & & & 0.2 & 0.5 & & \\
\hline Terpinen-4-ol & 1176 & 1174 & 0.5 & 0.3 & 0.2 & 0.2 & 0.1 & 0.6 & 1.0 & 0.9 & 0.6 & 0.5 & 0.8 & 0.4 \\
\hline a-Terpineol & 1186 & 1186 & & & & & & 0.1 & 0.3 & & 0.1 & 0.1 & 0.1 & 0.1 \\
\hline Thymol methyl ether & 1231 & 1232 & 0.9 & 0.9 & 0.4 & 0.4 & 0.1 & 0.9 & 1.8 & 1.7 & 1.7 & 1.7 & 1.6 & 1.7 \\
\hline Thymol & 1296 & 1289 & 72.3 & 75.6 & 78.4 & 80.0 & 77.8 & 78.0 & 70.1 & 67.3 & 65.7 & 71.6 & 72.5 & 72.3 \\
\hline Thymol acetate & 1354 & 1349 & 9.6 & 5.1 & 7.3 & 8.0 & 13.7 & 9.2 & 8.7 & 6.2 & 7.1 & 6.4 & 4.8 & 5.1 \\
\hline Eugenol & 1355 & 1356 & & & & & 0.2 & 0.1 & & 0.1 & & & 0.1 & 0.1 \\
\hline a-Copaene & 1372 & 1374 & 0.1 & & & & 0.4 & 0.1 & 0.1 & 0.1 & 0.1 & 0.1 & 0.1 & \\
\hline Methyleugenol & 1401 & 1403 & 0.1 & & & & 0.1 & 0.1 & 0.1 & & & 0.1 & 0.1 & 0.1 \\
\hline (E)-caryophyllene & 1419 & 1417 & 4.5 & 2.9 & 6.2 & 4.1 & 4.5 & 4.1 & 5.5 & 5.4 & 5.5 & 4.9 & 4.4 & 3.9 \\
\hline trans-a-Bergamotene & 1433 & 1432 & 0.2 & & 0.1 & & 0.1 & 0.1 & 0.2 & 0.1 & & 0.1 & 0.1 & 0.1 \\
\hline Aromadendrene & 1439 & 1439 & & & & & & 0.1 & 0.1 & 0.1 & 0.1 & 0.1 & 0.1 & 0.1 \\
\hline 6,9-Guaiadiene & 1442 & 1442 & 0.6 & & & & & & & & & & & \\
\hline a-Humulene & 1454 & 1452 & & 0.4 & 0.8 & 0.5 & 0.5 & 0.7 & 0.8 & 0.7 & 0.8 & 0.7 & 0.6 & 0.5 \\
\hline Y-Muurolene & 1479 & 1478 & 0.1 & & 0.1 & 0.1 & & 0.1 & 0.2 & 0.2 & 0.2 & 0.1 & 0.1 & 0.1 \\
\hline Germacrene D & 1485 & 1484 & 0.1 & 0.4 & 0.5 & 0.3 & 0.3 & 0.2 & 0.6 & 0.2 & 0.6 & 0.8 & 0.4 & 0.5 \\
\hline Y-Amorphene & 1497 & 1495 & & & 0.1 & & & 0.1 & 0.1 & 0.1 & 0.1 & 0.1 & 0.1 & 0.1 \\
\hline Viridiflorene & 1498 & 1496 & & & & & & & & & 0.1 & 0.1 & 0.1 & 0.1 \\
\hline a-Muurolene & 1501 & 1500 & 0.1 & & & & 0.1 & 0.1 & 0.1 & 0.1 & & 0.1 & 0.1 & 0.1 \\
\hline$\delta$-Amorphene & 1512 & 1511 & & & & & & 0.1 & 0.1 & 0.1 & 0.1 & 0.1 & 0.1 & 0.1 \\
\hline Y-Cadinene & 1514 & 1513 & 0.1 & 0.1 & 0.1 & 0.1 & 0.1 & 0.1 & & 0.1 & 0.2 & 0.1 & 0.1 & 0.1 \\
\hline$\delta$-Cadinene & 1524 & 1522 & 0.2 & 0.1 & 0.3 & 0.1 & 0.1 & 0.3 & 0.1 & 0.3 & 0.4 & 0.2 & 0.2 & 0.1 \\
\hline trans-Calamenene & 1525 & 1521 & & & & & & 0.1 & 0.1 & & 0.1 & 0.1 & 0.1 & \\
\hline a-Cadinene & 1538 & 1537 & & & & & & 0.1 & 0.1 & 0.1 & 0.1 & 0.1 & 0.1 & \\
\hline Caryophyllene oxide & 1582 & 1582 & 0.3 & & & 0.3 & 0.2 & 0.5 & 0.4 & 0.2 & 0.3 & 0.3 & 0.3 & 0.3 \\
\hline Humulene epoxide II & 1607 & 1608 & & 0.2 & 0.4 & & 0.1 & 0.1 & 0.1 & 0.1 & 0.1 & 0.1 & 0.1 & 0.1 \\
\hline a-Cadinol & 1654 & 1652 & 0.1 & & 0.1 & & & 0.1 & 0.1 & 0.1 & 0.1 & 0.1 & 0.1 & 0.1 \\
\hline 14-Hydroxy-9-epi-(E)-caryophyllene & 1670 & 1668 & & & & & & 0.1 & 0.1 & 0.1 & 0.1 & 0.1 & 0.1 & 0.1 \\
\hline
\end{tabular}


Table 2 (continued)

\begin{tabular}{|c|c|c|c|c|c|c|c|c|c|c|c|c|c|c|}
\hline \multirow[t]{3}{*}{ Oil constituents (\%) } & \multicolumn{14}{|c|}{ Oil yields (\%) } \\
\hline & \multirow[t]{2}{*}{$\mathrm{RI}_{\mathrm{C}}$} & \multirow[t]{2}{*}{$\mathrm{RI}_{\mathrm{L}}$} & \multirow{2}{*}{$\begin{array}{l}1.3 \\
\text { Jan }\end{array}$} & \multirow{2}{*}{$\begin{array}{l}0.9 \\
\text { Feb }\end{array}$} & \multirow{2}{*}{$\begin{array}{l}0.7 \\
\text { Mar }\end{array}$} & \multirow{2}{*}{$\begin{array}{l}0.7 \\
\text { Apr }\end{array}$} & \multirow{2}{*}{$\begin{array}{l}0.3 \\
\text { May }\end{array}$} & \multirow{2}{*}{$\begin{array}{l}0.3 \\
\text { Jun }\end{array}$} & \multirow{2}{*}{$\begin{array}{l}0.7 \\
\text { Jul }\end{array}$} & \multirow{2}{*}{$\begin{array}{l}0.4 \\
\text { Aug }\end{array}$} & \multirow{2}{*}{$\begin{array}{l}0.7 \\
\text { Sep }\end{array}$} & \multirow{2}{*}{$\begin{array}{l}1.0 \\
\text { Oct }\end{array}$} & \multirow{2}{*}{$\begin{array}{l}1.3 \\
\text { Nov }\end{array}$} & \multirow{2}{*}{$\begin{array}{l}1.3 \\
\text { Dec }\end{array}$} \\
\hline & & & & & & & & & & & & & & \\
\hline Monoterpenes hydrocarbons & & & 8.6 & 13.1 & 4.4 & 5.5 & 1.2 & 2.0 & 7.1 & 13.7 & 13.2 & 9.3 & 11.5 & 12.5 \\
\hline Oxygenated monoterpenes & & & 83.6 & 82.3 & 86.5 & 88.7 & 91.8 & 89.3 & 82.9 & 77.1 & 76.3 & 81.6 & 80.4 & 80.3 \\
\hline Sesquiterpene hydrocarbons & & & 6.0 & 3.9 & 8.2 & 5.2 & 6.1 & 6.3 & 8.1 & 7.6 & 8.4 & 7.7 & 6.7 & 5.8 \\
\hline Oxygenated sesquiterpenes & & & 0.4 & 0.2 & 0.5 & 0.3 & 0.3 & 0.8 & 0.7 & 0.5 & 0.6 & 0.6 & 0.6 & 0.6 \\
\hline Other compounds & & & 0.1 & 0.1 & 0.1 & & 0.3 & 0.4 & 0.3 & 0.3 & 0.2 & 0.3 & 0.4 & 0.4 \\
\hline Total & & & 98.7 & 99.6 & 99.7 & 99.7 & 99.7 & 98.8 & 99.1 & 99.2 & 98.7 & 99.5 & 99.6 & 99.6 \\
\hline
\end{tabular}

$\mathrm{Rl}_{\mathrm{C}}$ : calculated retention index (DB-5 ms column); $\mathrm{RI}_{\mathrm{L}}$ : literature retention index (Adams [17]); Main constituents in italics

as L. glandulosa Schauer sampled in the Lavrado area of Roraima state, Brasil [21], L. origanoides Kunth (thymol-type) collected in Bucaramanga, Santander District, Colombia [22], and L. gracilis Schauer harvested in Balsas, Maranhão state, Brasil [23]. This way could consider that these thymol-type oils may result from the polymorphism of some different Lippia species, mainly taking into account the climatic factors of the collection sites.

\section{Variability in oil composition}

The multivariate analysis of PCA (Principal Component Analysis) (Fig. 2) and HCA (Hierarchical Cluster Analysis) (Fig. 3) was applied to the monoterpene hydrocarbons $(\mathrm{MH})$, oxygenated monoterpenes (OM), and sesquiterpene hydrocarbons $(\mathrm{SH})$, quantified in the oils of seasonal study, in association with temperature, solar radiation, relative humidity, and precipitation, the seasonal variables at the plant collection site. The main components (PC1 and PC2) presented a proportional variance of $54 \%$ and $21.8 \%$ respectively, and the total variation of $75.8 \%$ in the PCA analysis. The CP1 component was mainly responsible for separating the two groups formed in Fig. 2. The HCA analysis, considering the Euclidean distances and complete bonds, confirmed the formation of two distinct groups, as observed in the dendrogram of Fig. 3. Group 1 is associated with the variables from January to July, characterized by the higher content of oxygenated monoterpenes (82.3-91.8\%) and is related to temperature variation and precipitation. During these months, a low temperature was registered, between 23.1 and $26.5{ }^{\circ} \mathrm{C}$, and the highest level of precipitation, between 180 and $540 \mathrm{~mm}$. The group II, represented by the months of August to December, is characterized by the higher content of monoterpene hydrocarbons (9.3 to $13.7 \%$ ) and sesquiterpene hydrocarbons (5.8 to $8.4 \%$ ), and related to a low relative humidity (57.5 to $70.3 \%)$ and to the highest solar radiation (1123 to $1219 \mathrm{~kJ} / \mathrm{m}^{2}$ ) observed in the seasonal period.
The composition of the oils in the circadian study, during the rainy $(\mathrm{R})$ and dry (D) periods (Table 3 ), presented on average the following primary constituents: thymol (R: 74.3\%; D: 64.5\%), $\gamma$-terpinene (R: 5.4\%; D: $7.6 \%)$, thymol acetate (R: $5.4 \% ; \mathrm{D}: 6.3 \%), p$-cymene (R: 6.0\%; D: 6.7\%), and (E)-caryophyllene (R: 3.3\%; D: $5.1 \%)$. Thymol showed a higher percentage in the rainy season, while $\gamma$-terpinene, thymol acetate, $p$-cymene and $(E)$-caryophyllene showed higher levels in the dry period.

Similarly, PCA and HCA studies were applied to the constituents identified in oils from the rainy and dry periods of the circadian study (Figs. 4 and 5). The main components (PC1 and PC2) presented a proportional variance of $49.6 \%$ and $25.3 \%$ respectively, and the total variation of $74.9 \%$ in the PCA analysis. The HCA analysis, considering the Euclidean distances and complete bonds, confirmed the formation of two distinct groups, as observed in the dendrogram of Fig. 5. Group I was formed with the constituents of the oils resulting from L. thymoides collections, in a daily cycle of the rainy season (February), characterized by the higher thymol content, followed by the minor percent of $(Z)$-hexen3 -ol, $\alpha$-thujene, $\alpha$-pinene, $\alpha$-phellandrene and humulene epoxide II. Group II resulted from the grouping of the oils of the plant samples collected during 1 day in the dry period (September) and it was characterized by a higher content of $p$-cymene, $\gamma$-terpinene, thymol acetate and $(E)$-caryophyllene, followed by a lower percentage of myrcene, $\alpha$-terpinene, 1,8-cineole, terpinen-4-ol, methylthymol, and germacrene $\mathrm{D}$.

It is widely known that essential oils can vary in composition depending on the place, time of day and seasonality. Therefore, these different chemical profiles must be associated with the environmental conditions existing at their respective collection sites. The knowledge of this variation in the composition of L. Thymoides oil is essential from the ecological and taxonomic point of 
Table 3 Circadian study of the Lippia thymoides oils on the rainy and dry seasons

\begin{tabular}{|c|c|c|c|c|c|c|c|c|c|c|c|c|c|c|}
\hline \multirow[t]{4}{*}{ Oil constituents (\%) } & \multicolumn{14}{|c|}{ Oil yields (\%) } \\
\hline & \multirow[t]{3}{*}{$\mathrm{RI}_{\mathrm{C}}$} & \multirow[t]{3}{*}{$\mathbf{R I}_{\mathbf{L}}$} & \multicolumn{6}{|c|}{ February-rainy season } & \multicolumn{6}{|c|}{ September-dry season } \\
\hline & & & 0.9 & 0.9 & 1.1 & 0.9 & 0.7 & 0.8 & 0.7 & 0.9 & 0.8 & 0.5 & 0.8 & 0.6 \\
\hline & & & $6 \mathrm{am}$ & $9 \mathrm{am}$ & $12 \mathrm{am}$ & $3 \mathrm{pm}$ & $6 \mathrm{pm}$ & $9 \mathrm{pm}$ & $6 \mathrm{am}$ & $9 \mathrm{am}$ & $12 \mathrm{am}$ & $3 \mathrm{pm}$ & $6 \mathrm{pm}$ & $9 \mathrm{pm}$ \\
\hline (3Z)-Hexenol & 853 & 850 & 0.1 & 0.1 & 0.1 & 0.2 & 0.1 & 0.1 & 0.1 & & 0.1 & & & 0.1 \\
\hline a-Thujene & 922 & 924 & 0.6 & 1.0 & 1.2 & 1.4 & 0.7 & 1 & 0.1 & 0.2 & 0.5 & 0.7 & 0.4 & 0.8 \\
\hline a-Pinene & 934 & 932 & & 0.1 & 0.1 & 0.1 & & 0.1 & & 0.1 & 0.1 & 0.1 & 0.1 & \\
\hline Camphene & 948 & 946 & & & 0.1 & 0.1 & & & & & 0.1 & & 0.1 & \\
\hline Sabinene & 971 & 969 & & & & & & & & 0.1 & & 0.1 & 0.1 & \\
\hline$\beta$-Pinene & 978 & 974 & 0.1 & & 0.2 & 0.2 & & & & & & & & 0.1 \\
\hline 1-Octen-3-ol & 979 & 974 & & & & & & & 0.1 & 0.1 & 0.1 & 0.1 & 0.1 & 0.2 \\
\hline Myrcene & 987 & 988 & 1.0 & 1.0 & 1.2 & 1.5 & 1.0 & 1 & 0.6 & 0.6 & 0.8 & 1.6 & 1.2 & 1.8 \\
\hline a-Phellandrene & 1000 & 1002 & 0.1 & 0.1 & 0.1 & 0.1 & 0.1 & 0.1 & & 0.1 & 0.1 & 0.1 & 0.1 & 0.1 \\
\hline iso-Sylvestrene & 1007 & 1007 & & & & & & & 0.1 & 0.1 & 0.1 & 0.1 & 0.1 & 0.1 \\
\hline a-Terpinene & 1015 & 1014 & & 0.7 & & 1.2 & 0.7 & 0.6 & 0.9 & 0.9 & 1.1 & 1.6 & 1.3 & 1.5 \\
\hline p-Cymene & 1022 & 1020 & 6.4 & 4.7 & 7.8 & 6.7 & 5.5 & 4.7 & 4.8 & 4.1 & 7.0 & 8.4 & 6.8 & 8.8 \\
\hline Limonene & 1025 & 1024 & & & & 0.2 & & & 0.2 & 0.2 & 0.2 & 0.3 & 0.3 & 0.4 \\
\hline 1,8-Cineole & 1028 & 1026 & & & & 0.3 & & & 0.5 & 0.3 & 0.4 & 0.6 & 0.6 & 0.8 \\
\hline (E)- $\beta$-Ocimene & 1047 & 1044 & & & 0.1 & 0.1 & & & 0.1 & & 0.1 & 0.1 & 0.1 & 0.1 \\
\hline y-Terpinene & 1058 & 1054 & 4.9 & 4.9 & 5.8 & 6.8 & 4.8 & 4.9 & 6.4 & 7.0 & 8.3 & 8.4 & 8.0 & 7.6 \\
\hline cis-Sabinene hidrate & 1064 & 1063 & 0.1 & 0.1 & 0.1 & 0.1 & 0.1 & 0.1 & 0.1 & & & & & \\
\hline Terpinolene & 1087 & 1086 & & & 0.1 & 0.1 & & & 0.1 & 0.1 & 0.1 & 0.1 & 0.1 & 0.1 \\
\hline Linalool & 1094 & 1095 & 0.1 & 0.1 & 0.1 & 0.1 & 0.1 & 0.1 & 0.1 & 0.1 & 0.1 & 0.1 & 0.1 & 0.1 \\
\hline Camphor & 1143 & 1141 & & & & 0.1 & & & 0.1 & 0.1 & 0.1 & 0.1 & 0.1 & 0.1 \\
\hline Umbellulone & 1169 & 1167 & 0.2 & 0.1 & 0.1 & 0.1 & 0.1 & 0.1 & 0.2 & 0.2 & 0.2 & & 0.1 & 0.2 \\
\hline Terpinen-4-ol & 1176 & 1174 & & & & & & 0.1 & 0.1 & 0.1 & 0.1 & & 0.1 & 0.3 \\
\hline a-Terpineol & 1186 & 1186 & 0.4 & 0.1 & 0.2 & 0.3 & & & 0.6 & 0.5 & 0.4 & 0.6 & 0.4 & \\
\hline Thymol methyl ether & 1231 & 1232 & 0.9 & 0.4 & 0.7 & 0.7 & 0.4 & 0.4 & 1.7 & 1.5 & 1.0 & 1.1 & 1.2 & 1.2 \\
\hline Thymol & 1296 & 1289 & 75.6 & 77.7 & 70.0 & 66.6 & 77.8 & 77.8 & 65.7 & 65.9 & 67.8 & 62.6 & 61.5 & 63.2 \\
\hline Thymol acetate & 1354 & 1349 & 5.1 & 4.6 & 6.0 & 7.3 & 4.5 & 4.6 & 7.1 & 9.0 & 4.5 & 5.5 & 6.9 & 4.7 \\
\hline Eugenol & 1355 & 1354 & 0.1 & & & & & & & 0.1 & 0.1 & 0.1 & 0.1 & \\
\hline a-Copaene & 1372 & 1374 & & & 0.1 & & & & 0.1 & 0.1 & 0.1 & 0.1 & & \\
\hline (E)-Caryophyllene & 1419 & 1417 & 2.9 & 3.3 & 3.8 & 3.6 & 3.0 & 3.3 & 5.7 & 5.1 & 4.1 & 4.3 & 6.3 & 4.8 \\
\hline trans-a-Bergamotene & 1433 & 1432 & & & 0.1 & 0.1 & & & & 0.1 & 0.1 & 0.1 & 0.2 & 0.2 \\
\hline Aromadendrene & 1439 & 1439 & & & & & & & 0.1 & 0.1 & 0.1 & & & \\
\hline a-Humulene & 1454 & 1452 & 0.4 & 0.3 & 0.5 & 0.4 & 0.3 & 0.3 & 0.8 & 0.8 & 0.5 & 0.6 & 0.9 & 0.7 \\
\hline Y-Muurolene & 1479 & 1478 & & 0.1 & 0.1 & 0.1 & & 0.1 & 0.2 & 0.1 & 0.1 & 0.1 & 0.2 & 0.1 \\
\hline Germacrene D & 1485 & 1484 & 0.4 & 0.3 & 0.6 & 0.5 & 0.3 & 0.3 & 0.7 & 0.8 & 0.4 & 0.6 & 0.9 & 0.7 \\
\hline Y-Amorphene & 1497 & 1495 & & & & & & & 0.1 & 0.1 & 0.1 & 0.1 & 0.1 & \\
\hline a-Muurolene & 1501 & 1500 & & & 0.1 & & & & & 0.1 & 0.1 & 0.1 & 0.1 & \\
\hline$\delta$-Amorphene & 1512 & 1511 & & & & & & & 0.1 & & 0.1 & 0.1 & & \\
\hline$\gamma$-Cadinene & 1514 & 1513 & 0.1 & & 0.1 & 0.1 & & & 0.2 & 0.1 & 0.1 & 0.1 & 0.1 & 0.1 \\
\hline$\delta$-Cadinene & 1524 & 1522 & 0.1 & 0.1 & 0.1 & 0.1 & & 0.1 & 0.4 & 0.2 & 0.2 & 0.2 & 0.3 & 0.2 \\
\hline a-Cadinene & 1538 & 1537 & & & & 0.1 & & & 0.1 & 0.1 & 0.1 & 0.1 & & \\
\hline Humulene epoxide II & 1607 & 1608 & & & & & & & 0.3 & 0.3 & 0.2 & 0.3 & 0.3 & 0.3 \\
\hline a-Cadinol & 1654 & 1652 & 0.2 & 0.1 & 0.2 & 0.2 & 0.1 & 0.1 & 0.1 & 0.1 & 0.1 & 0.1 & 0.1 & \\
\hline 14-Hydroxi-9-epi-(E)-caryophyllene & 1670 & 1668 & & & & & & 0.1 & 0.1 & 0.1 & 0.1 & 0.1 & 0.1 & 0.1 \\
\hline Monoterpene hydrocarbons & & & 13.1 & 12.5 & 16.7 & 18.5 & 12.8 & 12.4 & 13.3 & 13.5 & 18.5 & 21.6 & 18.7 & 21.4 \\
\hline
\end{tabular}


Table 3 (continued)

\begin{tabular}{|c|c|c|c|c|c|c|c|c|c|c|c|c|c|c|}
\hline \multirow[t]{3}{*}{ Oil constituents (\%) } & \multicolumn{14}{|c|}{ Oil yields (\%) } \\
\hline & \multirow[t]{3}{*}{$\mathrm{RI}_{\mathrm{C}}$} & \multirow[t]{3}{*}{$\mathbf{R I}_{\mathbf{L}}$} & \multicolumn{6}{|c|}{ February-rainy season } & \multicolumn{6}{|c|}{ September-dry season } \\
\hline & & & 0.9 & 0.9 & 1.1 & 0.9 & 0.7 & 0.8 & 0.7 & 0.9 & 0.8 & 0.5 & 0.8 & 0.6 \\
\hline & & & $6 \mathrm{am}$ & $9 \mathrm{am}$ & $12 \mathrm{am}$ & $3 \mathrm{pm}$ & $6 \mathrm{pm}$ & $9 \mathrm{pm}$ & $6 \mathrm{am}$ & $9 \mathrm{am}$ & $12 \mathrm{am}$ & $3 \mathrm{pm}$ & $6 \mathrm{pm}$ & $9 \mathrm{pm}$ \\
\hline Oxygenated monoterpenes & & & 82.4 & 83.1 & 77.2 & 75.6 & 83.0 & 83.2 & 76.2 & 77.7 & 74.6 & 70.6 & 71.0 & 70.6 \\
\hline Sesquiterpene hydrocarbons & & & 3.9 & 4.1 & 5.5 & 5.0 & 3.6 & 4.1 & 8.5 & 7.7 & 6.1 & 6.5 & 9.1 & 6.8 \\
\hline Oxygenated sesquiterpenes & & & 0.2 & 0.1 & 0.2 & 0.2 & 0.1 & 0.1 & 0.5 & 0.5 & 0.4 & 0.5 & 0.5 & 0.4 \\
\hline Other compounds & & & 0.2 & 0.1 & 0.1 & 0.2 & 0.1 & 0.1 & 0.2 & 0.2 & 0.3 & 0.2 & 0.2 & 0.3 \\
\hline Total (\%) & & & 99.8 & 99.9 & 99.7 & 99.5 & 99.6 & 99.9 & 98.7 & 99.6 & 99.9 & 99.4 & 99.5 & 99.5 \\
\hline
\end{tabular}

$\mathrm{RI}_{c}$ : calculated retention index (DB-5 ms column); $\mathrm{RI}_{L}$ : literature retention index (Adams [17]); Main constituents in italics

view, regarding the management and economic use of the species.

As already mentioned, Lippia thymoides is a species little studied from the phytochemical point of view. Literature report methylthymol as the main constituent of the essential oil of a specimen of $L$. thymoides described to Brazil, but with an unknown collection site $[24,25]$. Two other specimens with occurrence in the State of Bahia, Brazil, were reported to have essential oil rich in $(E)$-caryophyllene $[9,10]$. Also, there is another citation of a specimen collected in the State of Pará, Brazil, whose main constituent was thymol [11]. Thus, based on the information obtained in the literature and the present study, the essential oil of $L$. thymoides has shown the following chemical types: methylthymol, $(E)$-caryophyllene and thymol.

Thymol, methylthymol, thymol acetate, $p$-cymene, and $\gamma$-terpinene are all monoterpene constituents that occur together in many other essential oils, particularly in Lippia species [21-23]. All these constituents are derived from the same biosynthetic pathway in the plant, where $\gamma$-terpinene is considered the biogenetic precursor of the other monoterpenes [26, 27].

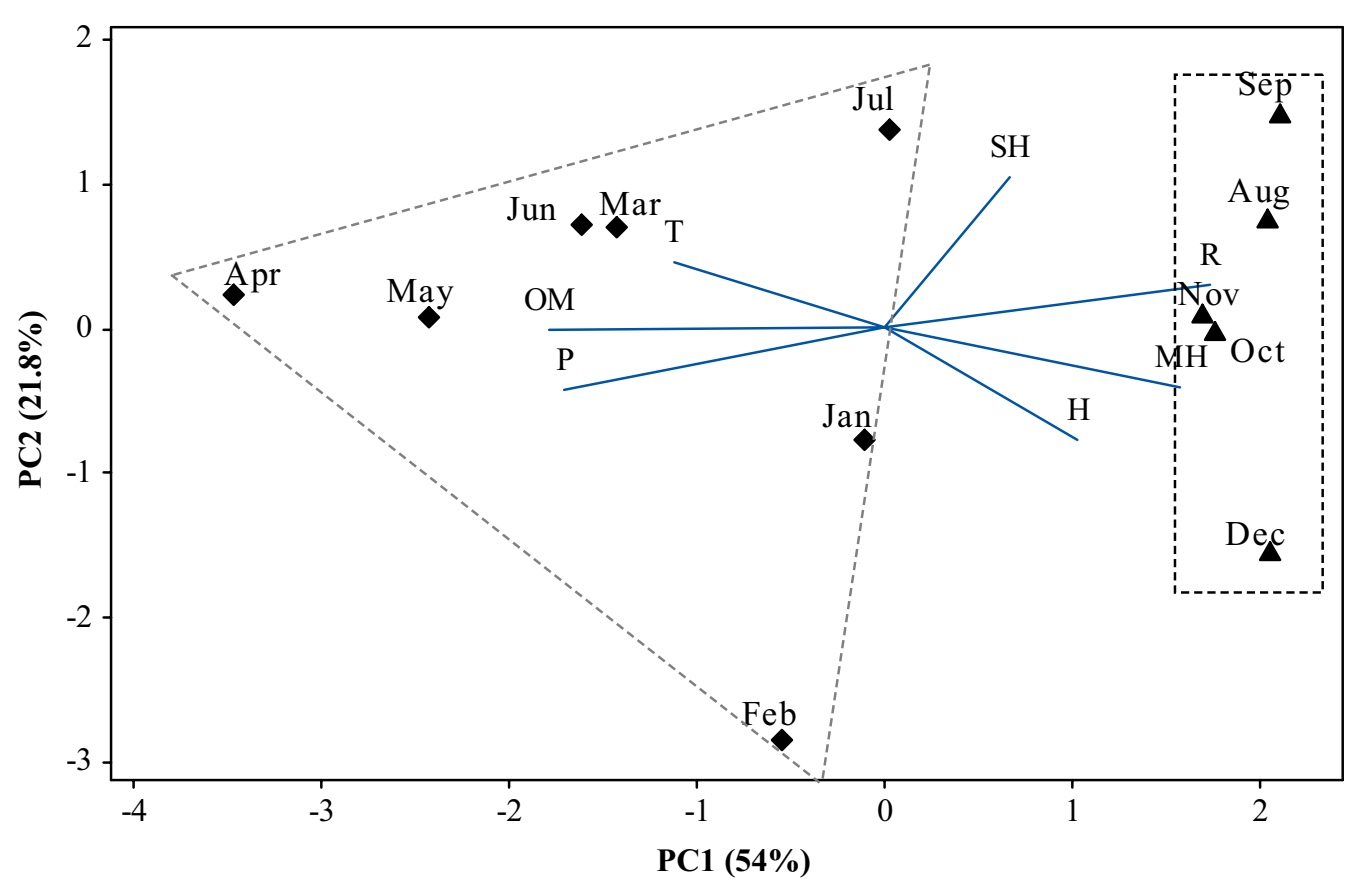

Fig. 2 Biplot (PCA) resulting from the analysis of the classes of compounds identified in the oils of $L$. thymoides of the seasonal study, in association with temperature, solar radiation, relative humidity, and precipitation 


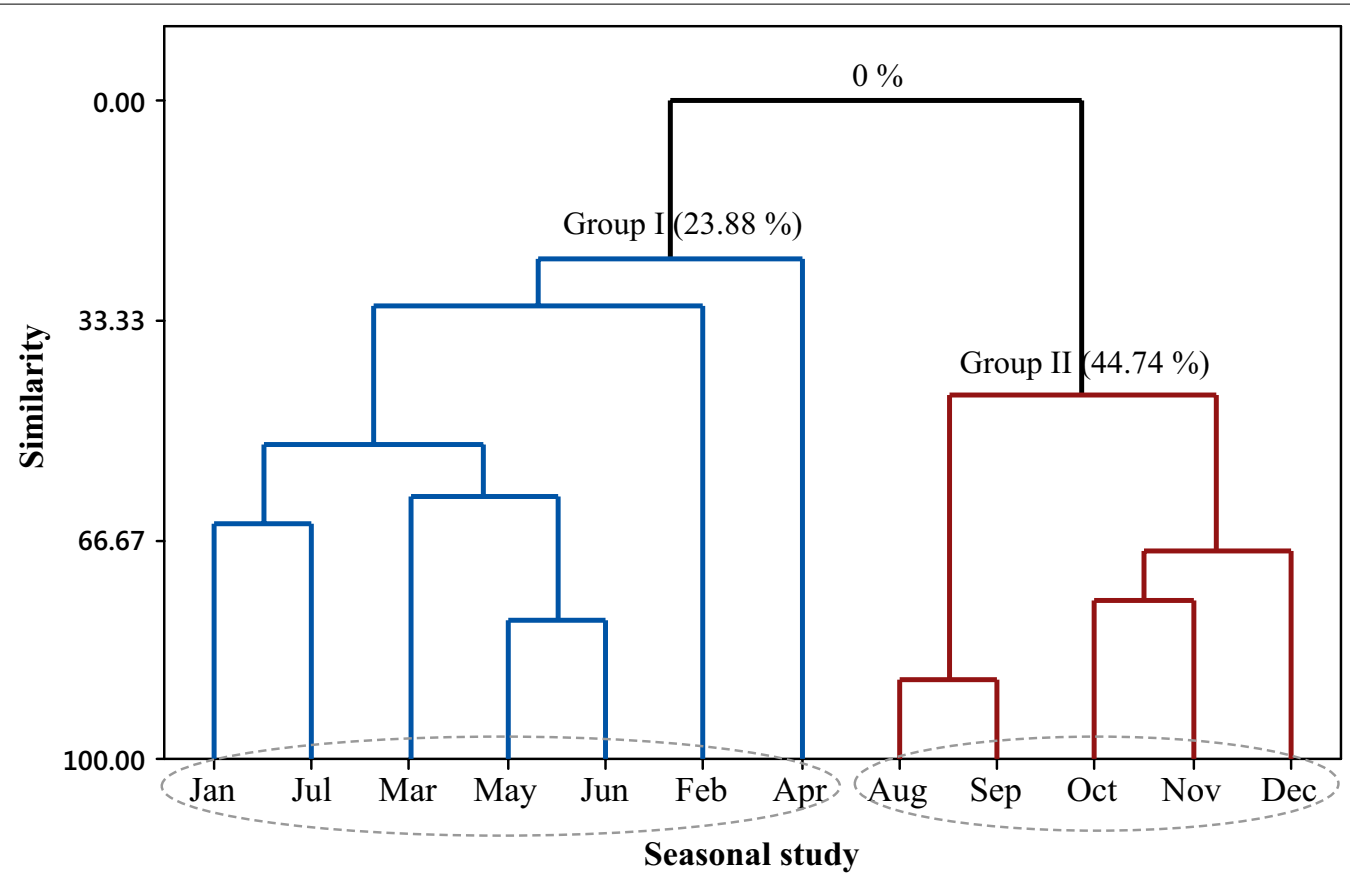

Fig. 3 Dendrogram representing the similarity relationship of the classes of compounds identified in the oils of L. thymoides in the seasonal study, in association with temperature, solar radiation, relative humidity and precipitation

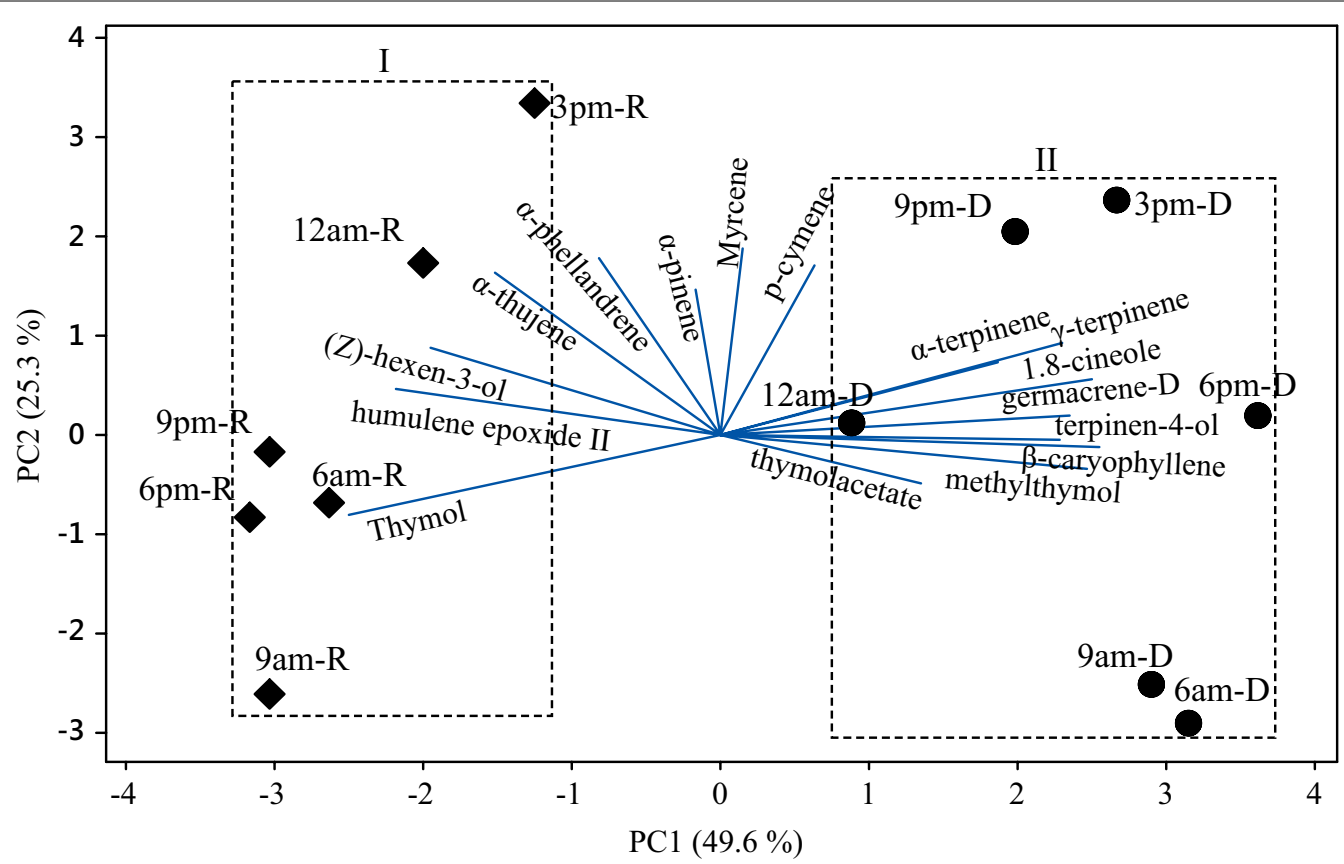

Fig. 4 Biplot (PCA) resulting from the analysis of the oil constituents of L. thymoides in the circadian study, during the rainy (R, February) and dry ( $D$, September) seasons 


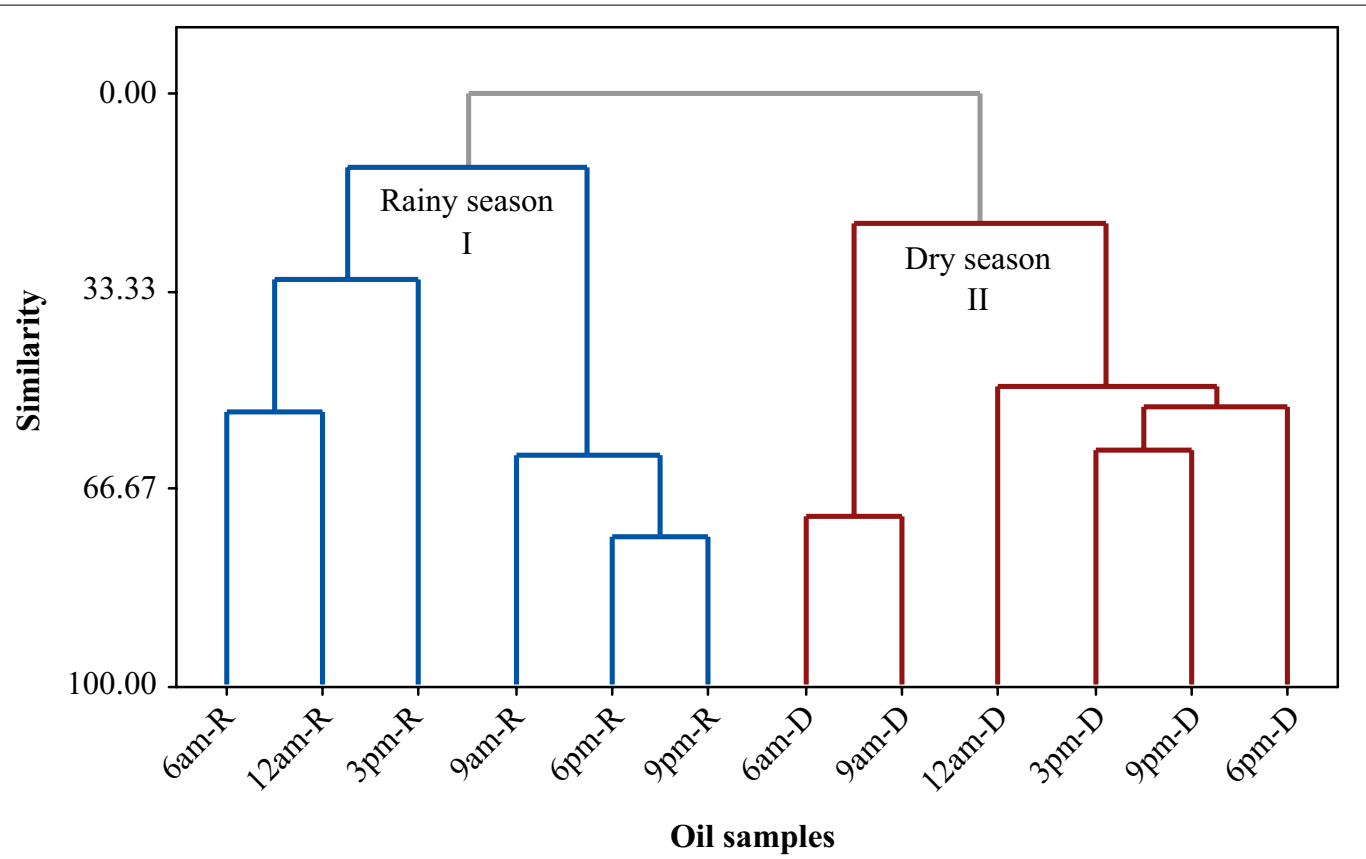

Fig. 5 Dendrogram representing the similarity relationship of the oils composition of L. thymoides in the circadian study, during the rainy ( $R$, February) and dry (D, September) season

\section{Conclusions}

Planting of L. thymoides showed excellent development, reaching about $1 \mathrm{~m}$ in length in 6 months. On average, the oil yield was $0.7 \%$ in the rainy season and $0.9 \%$ in the dry period, showing no significant statistical difference. In the seasonal study, the oil yield presented a strong correlation with the relative humidity. In the circadian evaluation, the correlation was with the temperature. In the annual survey, the rainy period showed the highest content of oxygenated monoterpenes, in association with the temperature and precipitation of the planting local. The mean thymol content was higher in the rainy season than in the dry period. The climatic variables that most influenced the thymol content were rainfall precipitation and solar radiation. These different chemical profiles must be associated with the environmental conditions existing at their respective collection sites. The knowledge of this variation in the composition of $L$. Thymoides oil is essential from the ecological and taxonomic point of view, regarding the management and economic use of the species.

\section{Abbreviations}

HCA: Hierarchical Cluster Analysis; PCA: Principal Component Analysis; GC: Gas chromatography; GC-MS: Gas chromatography-Mass spectrometry; INMET: Instituto Nacional de Meteorologia; EIMS: eletron ionization mass spectrometry; R: rainy season; D: dry season.

\section{Authors' contributions}

SGS participated in the planting, collection, and preparation of the plants to the herbaria, run the laboratory work, analyzed the data and help with the drafted paper. LDN and WAC helped with lab work. PLBF helped with lab work and data analysis. JGSM helped with the data analysis and drafted the manuscript. EHAA proposed the work plan, guided the laboratory work and drafted the manuscript. All authors read and approved the final manuscript.

\section{Author details}

${ }^{1}$ Programa de Pós-Graduação em Química, Universidade Federal do Pará, Belém, PA 66075-900, Brazil. ${ }^{2}$ Programa de Pós-Graduação em Engenharia de Recursos Naturais da Amazônia, Universidade Federal do Pará, Belém, PA 66075-900, Brazil. ${ }^{3}$ Coordenação de Botânica, Museu Paraense Emílio Goeldi, Belém, PA 66077-530, Brazil.

\section{Acknowledgements}

The authors would like to thank Secretaria de Educação do Estado do Pará (SECUC-PA) and CAPES, the research funding agency of the Brazilian government, for the scholarship and financial support.

\section{Competing interests}

The authors declare that they have no competing interests.

\section{Ethics approval and consent to participate}

Not applicable.

\section{Publisher's Note}

Springer Nature remains neutral with regard to jurisdictional claims in published maps and institutional affiliations.

Received: 6 August 2018 Accepted: 3 November 2018

Published online: 12 November 2018 


\section{References}

1. O'Leary N, Denham SS, Salimena F, Múlgura ME (2012) Species delimitation in Lippia section Goniostachyum (Verbenaceae) using the phylogenetic species concept. Bot J Linn Soc 170:197-219

2. http://floradobrasil.jbrj.gov.br/reflora. Accessed July 2018

3. Funch LS, Harley RM, Funch R, Giulietti AM, Melo E (2004) Plantas Úteis da Chapada Diamantina. Rima, São Carlos

4. Salimena FRG, Mulgura M. Lippia. In: Lista de Espécies da Flora do Brasil. Jardim Botânico do Rio de Janeiro. 2015. http://floradobrasil.jbrj.gov.br/ jabot/floradobrasil/FB21457. Accessed 11 Apr 2018

5. de Almeida MZ (2011) Plantas Medicinais, 3rd edn. Edufba, Salvador

6. Costa PS, Souza EB, Brito EHS, Fontenelle ROS (2017) Atividade antimicrobiana e potencial terapêutico do gênero Lippia sensu lato (Verbenaceae). Hoehnea 44:158-171

7. Gobbo-Neto L, Lopes NP (2007) Plantas medicinais: fatores de influência no conteúdo de metabólitos secundários. Quím Nova 30:374-381

8. Hussain Al, Anwar F, Hussain Sherazi ST, Przybylski R (2008) Chemical composition, antioxidant and antimicrobial activities of basil (Ocimum basilicum) essential oils depends on seasonal variations. Food Chem 108:986-995

9. Craveiro AA, Fernandes AG, Andrade CHS, Matos FJA, Alencar JW, Machado MIL (1981) Óleos essenciais de Plantas do Nordeste. Edições UFC, Fortaleza

10. Silva FS, Menezes PMN, de Sá PGS, Oliveira ALDS, Souza EAA, da Silva JRGA, de Lima JT, Uetanabaro APT, Silva TRDS, Peralta ED, Lucchese AM (2015) Chemical composition and pharmacological properties of the essential oils obtained seasonally from Lippia thymoides. Pharm Biol $54: 25-34$

11. Zoghbi MGB, Andrade EHA (2014) Composição química dos óleos essenciais de plantas aromáticas comercializadas no Ver-o-Peso. In: Zoghbi MGB, Mota MGC, Conceição CCC (eds) Plantas aromáticas do Ver-o-Peso. UFRA/MPEG, Belém, pp 253-300

12. Menezes PMN, Oliveira HR, Brito MC, Paiva GO, Ribeiro LAA, Lucchese AM, Silva FS (2018) Spasmolytic and antidiarrheal activities of Lippia thymoides (Verbenaceae) essential oil. Nat Prod Res 4:1-3

13. Pinto CDP, Rodrigues VD, Pinto FDP, Pinto RDP, Uetanabaro APT, Pinheiro CSR, Gadea SFM, Silva TRDS, Lucchese AM (2013) Antimicrobial activity of Lippia species from the Brazilian semiarid region traditionally used as antiseptic and anti-infective agents. J Evid Based Complement Altern Med. https://doi.org/10.1155/2013/614501 (Article ID 614501)
14. Silva FS, de Menezes PMN, Sá PGS, Oliveira ALDS, Souza EAA, Bamberg VM, de Oliveira HR, de Oliveira SA, Araújo REE, Uetanabaro APT, da Silva TR, Almeida JRGDS, Lucchese AM (2015) Pharmacological basis for traditional use of the Lippia thymoides. J Evid Based Complement Altern Med. https://doi.org/10.1155/2015/463248 (Article ID 463248)

15. Biasi LA, Costa G (2003) Propagação vegetativa de Lippia alba. Cienc Rural 33:455-459

16. Maia JGS, Andrade EHA (2009) Data base of the Amazon aromatic plants and their essential oils. Quím Nova 32:595-622

17. Adams RP (2007) Identification of essential oil components by gas chromatography/mass spectrometry, 4th edn. Allured Publishing Corporation, Carol Stream

18. NIST-National Institute of Standars and Technology (2011) Mass Spectral Library (NIST/EPA/NIH, v.2.0d). The Nist Mass spectrometry Data Center, Gaithersburg

19. Loureiro RS, Saraiva JM, Saraiva I, Senna RC, Fredó AS (2014) Estudo dos eventos extremos de precipitação ocorridos em 2009 no Estado do Pará. Rev Bras Meteorol 29:83-94

20. Sarrazin SLF, da Silva LA, de Assunção APF, Oliveira RB, Calao VYP, da Silva R, Stashenko EE, Maia JGS, Mourão RHV (2015) Antimicrobial and seasona evaluation of the carvacrol-chemotype oil from Lippia origanoides Kunth. Molecules 20:1860-1871

21. Maia JGS, da Silva MHL, Andrade EHA, Carreira LMM (2005) Essential oil variation in Lippia glandulosa Schauer. J Essent Oil Res 17:676-680

22. Stashenko EE, Martínez JR, Ruíz CA, Arias G, Durán C, Salgar W, Cala M (2010) Lippia origanoides chemotype differentiation based on essential oil GC-MS and principal component analysis. J Sep Sci 33:93-103

23. Franco CS, Ribeiro AF, Carvalho NCC, Monteiro OS, da Silva JKR, Andrade EHA, Maia JGS (2014) Composition and antioxidant and antifungal activities of the essential oil from Lippia gracilis Schauer. Afr J Biotechnol 13:3107-3113

24. Terblanché FC, Kornelius G (1996) Essential oil constituents of the genus Lippia (Verbenaceae) — a literature review. J Essent Oil Res 8:471-485

25. Pascual ME, Slowing K, Carretero E, Sánchez Mata D, Villar A (2001) Lippia: traditional uses, chemistry and pharmacology — a review. J Etnopharmacol 76:201-214

26. Poulose AJ, Croteau R (1978) Biosynthesis of aromatic monoterpenes Arch Biochem Biophys 187:307-314

27. Poulose AJ, Croteau R (1978) Y-Terpinene synthetase: a key enzyme in the biosynthesis of aromatic monoterpenes. Arch Biochem Biophys 191:400-411
Ready to submit your research? Choose BMC and benefit from:

- fast, convenient online submission

- thorough peer review by experienced researchers in your field

- rapid publication on acceptance

- support for research data, including large and complex data types

- gold Open Access which fosters wider collaboration and increased citations

- maximum visibility for your research: over 100M website views per year

At BMC, research is always in progress.

Learn more biomedcentral.com/submissions 